\title{
Analysis Inventory Cost Jona Shop with EOQ Model
}

\author{
Abigail Vania $^{*}$, Hanni Yolina ${ }^{2}$ \\ ${ }^{1,2}$,Mathematics and Computer Science Department, School of Computer Science \\ Bina Nusantara University, \\ Jakarta, Indonesia 11480 \\ abigail.vania@binus.ac.id; hanni.yolina@binus.ac.id \\ *Correspondence: abigail.vania@binus.ac.id
}

\begin{abstract}
Jona Shop is located in Indonesia, Jakarta is currently having a problem. The problem is the shop's owner thinks that the inventory costs are too big especially for a powdered drink which brand is "Nutrisari". The author finishes an EOQ (Economic Order Quantity) model to minimize the inventory cost. The EOQ model is an old model but a valid model which still used now. Even the EOQ model is an old model, many researchers used EOQ model to minimize inventory cost until $50 \%$ or more than $50 \%$. But the EOQ model has some assumptions and Jona Shop fulfilled all the assumptions in the EOQ model. The authors use five steps to get the result, there are data collection; compute data for calculating the ordering cost, holding cost, demand, lead time, the number of units ordered per order and frequency ordering per year; calculate total annual cost; calculate with EOQ model and calculate the frequency order, how many units need for each order and the reorder point; conclusion, the authors compare from actual data with the calculation of EOQ model. The result of the EOQ model can save up to almost $90 \%$.
\end{abstract}

Keywords: EOQ model, inventory costs, Economic Order Quantity, total inventory cost

\section{INTRODUCTION}

EOQ (Economic Order Quantity) model is an old model (Riza, Purba, \& Mukhlisin, 2018),(Datta \& Pal, 1988). EOQ is a method that can be used to arrange the procurement and storage of supplies (Kumar, 2016). Even if EOQ is an old model, it's still a valid method to be used. For example, used the EOQ model to reduce inventory costs in $\mathrm{ABC}$ company, even the actual cost is $50 \%$ approximately bigger than the EOQ model estimation and use safety stock to avoid any problems that occur with inventory (Jiraruttrakul, Smutkupt, Marksin, Liu, \& Thanathawee, 2017). Even the EOQ model is still used, it's developing corresponding to the needs like demand and partial backlogging (Mishra, 2016), then developing economic lot size model for price-dependent demand under quality and freight discounts (Burwell, Dave, Fitzpatrick, \& Roy, 1997), other than that it's developing for backorder level (Huang \& Wu, 2016), for perishable goods with age-dependent demand rate (Dobson, Pinker, \& Yildiz, 2017), for decaying item with full advanced payment and conditional discount (Tavakoli \& Taleizadeh, 2017). Even all the researchers before have written with the aim to reduce inventory cost to a minimum. Although the EOQ model has begun to develop according to the needs as described above. All of the studies that have been written above have one main goal in common, namely reducing inventory costs. According to the authors, the EOQ classic model is very easy to use, but not suitable for companies or stores that have been doing inventory for more than two years because it is no longer relevant. Usually using the EOQ model that suits your needs such as the EOQ model for demand and partial backlogging (Mishra, 2016), then developing economic lot size model for price-dependent demand under quality and freight discounts (Burwell, Dave, Fitzpatrick, \& Roy, 1997), other than that it's developing for backorder level (Huang \& Wu, 2016), for perishable goods with age-dependent demand rate (Dobson, Pinker, \& Yildiz, 2017), for decaying item with full advanced payment and conditional discount (Tavakoli \& Taleizadeh, 2017).

Jona Shop is a small shop in Indonesia, especially in Jakarta. Jona Shop has been established since 2019. Jona Shop sells various types of powdered drinks, but there is a problem with the stock of powdered drinks with the brand "Nutrisari". The owner of Jona Shop thinks that the inventory cost needed for Nutrisari is too much. So, it is needed for estimation of inventory control to decide when 
and how much Nutrisari needs to be ordered for an optimal result. But the owner cannot estimate it himself.

The author will use the EOQ (Economic Order Quantity) method because there are enough researchers who use EOQ to minimalize inventory cost and stock cost (Sari, Dur, \& Husein, 2020), (Umami, Mu'tamar, \& Rakhmawati, 2018), (Topowijono \& Sudjana, 2016), (Tipaka, Paendong, \& Mongi, 2017), (Fadly, Jaya, \& A.Sahari, 2016). Jona shop has only been established since 2019, which means that this store has only been doing inventory for about a year and there are not many unwanted possibilities that have occurred. Like one of them doing back-ordering because of running out of stock. So, the Jona shop is still feasible to use the classic EOQ model like ABC company to calculate the inventory cost for Beer Lager and Beer Dark, where ABC company only takes into account the last one year (Jiraruttrakul, Smutkupt, Marksin, Liu, \& Thanathawee, 2017). Because of that, the author's contribution is to help the shop owner to analyze the inventory costs. This research was done so the shop's owner didn't do the same mistake and be able to get the optimal result. To help solve this problem, we can develop it into several research questions, including, how many units should be ordered in each order, how many times to place an order in a year, how much ordering and storage costs should be incurred, and what is the total annual cost to be incurred for Nutrisari product.

From the estimation using the EOQ model, the author obtains a conclusion whenever using the EOQ method will reduce the total inventory cost, or before using the EOQ method the total cost already effective.

The purpose of writing this article is to provide information on how many times to place an optimal order, reorder points, and the minimum total cost but the optimal number of orders made, according to demand.

In part 2, the author will discuss the formula and terms in the EOQ model and the process to get the result. In part 3 , the author will compare the actual data with the EOQ model estimation result. In part 4, the author will conclude from the estimation and what the next researcher could do.

\section{METHODS}

The authors have done many steps to get the result. There are five steps the authors did in this article. First is data collection, the authors got data from the owner of Jona shop. Second is to compute data for calculating the ordering cost, holding cost, demand, lead time, the number of units ordered per order, and frequency ordering per year. Third is calculate the total annual cost. Fourth is calculate with the EOQ model and calculate the frequency order, how many units need for each order, and the reorder point. The last is give the conclusion, the authors compare actual data with the calculation of the EOQ model.

First step is data collection. The authors collected the data from April 2019 until March 2020. The authors collected the data of ordering cost, holding cost, demand. The authors record and count the total ordering cost and holding cost of each month, for demand calculated of each day. The author also collects data on the initial stock and end stock every day which is used to determine the demand per day. The ordering costs that are required from April 2019 to March 2020 are communication costs and transportation costs in the process of ordering each order. Then the holding costs needed from April 2019 to March 2020 are warehouse electricity costs and depreciation costs every month. The ordering cost and the holding cost each month are used to calculate the total ordering cost and the holding cost per year. In addition, the authors also collect data on how many times to place an order within a year and how many units are ordered in one order. Then, collected the data when the owner did the ordering and the product arrived at the shop.

Second step is to compute data and calculate the total cost of the order in one year. We calculate the cost of ordering based on the data obtained in the previous step. Where these costs are communication and transportation costs for each order, then they are added up from April 2019 to March 2020. After that, calculate the total holding costs. The holding costs that we get from the previous step are warehouse electricity costs and depreciation cost every month. Then we add it up from April 2019 to March 2020. In addition, we also see how long the data has been ordered after placing an order (lead time). Then add up the frequency of placing orders and the number of units ordered per order during the period April 2019 to March 2020. We calculate and add up within the period of one year because it will be compared with the EOQ model which results are per year. In order to be balanced in comparing, both are calculated per year.

Third step is to calculate the total annual cost. The total annual cost is the sum of ordering costs and holding costs. The cost of ordering which will be added up is the cost of ordering per year and the cost of holding that will be added is the cost of holding per year. Based on the data we obtained from the previous step, the cost of ordering is the accumulation of April 2019 to March 2020 period as well as the holding costs, the accumulated holding costs for the period April 2019 to March 2020.

Fourth step is calculated with the EOQ model to get frequency order, reorder point, and total cost from the EOQ model. The EOQ model is one of the oldest, and most general inventory control techniques to be used. The EOQ model was published by Ford W. Harris in 1915 (RENDER, RALPH M. STAIR, \& HANNA, 2012). The aim of this method is to minimize the total cost of inventory (Hoswari, Gozali, Marie, \& Sukania, 2019), (Riza, Purba, $\&$ Mukhlisin, 2018). But there is some assumption in using this method which are:

1. We know the demand and constant

2. We know the lead time and constant

3. We can estimate only one product

4. We can immediately use it when received in onetime delivery

5. If run out of stock, we can not backorder

6. There is no discount

7. The holding cost and the ordering cost per year are constant

According to Hoswari, Gozali, Marie, and Sukania (2019) says, inventory costs include ordering costs, holding costs, and shortage costs. But in the EOQ model there is no 
backorder because of run-out stock, so this model does not use shortage costs.

According to Kumar (2016) says that ordering costs include the cost of ordering the products, cost to communicate about the order, travel cost, daily allowance for the employee, transport cost, and the others. In ordering costs, the more order done then the less the total order.

According to Kumar (2016) says, holding costs include depreciation cost, shophouse cost, insurance cost, damage costs, and others. Figure 1 will show the location of EOQ to total cos, holding costs, and ordering costs. Where the EOQ is located in the most minimum total cost.

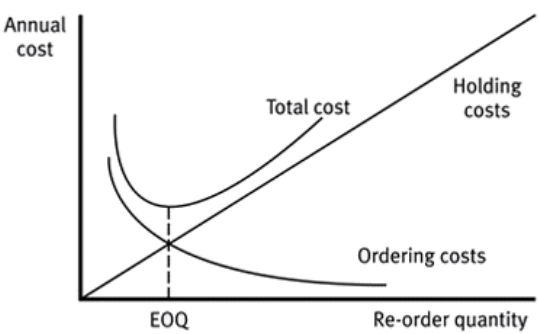

Figure 1 Total Cost (https://www.google.com/)

\section{Formulation of EOQ}

From the explanation above, it can be pictured in the EOQ formula as follows:

$$
\begin{gathered}
E O Q=Q^{*}=\sqrt{\frac{2 D C_{0}}{C_{h}}} \\
\text { Annual ordering cost }=\frac{D}{Q} C_{0} \\
\text { Annual holding cost }=\frac{Q}{2} C_{h} \\
\text { Total Cost }=\frac{D}{Q} C_{0}+\frac{Q}{2} C_{h} \\
\text { ROP (reorder point) }=d * L \\
\text { Frequency order }=\frac{D}{E O Q}
\end{gathered}
$$

Where,

$\mathrm{Q} \quad$ : number of pieces to order

$\mathrm{EOQ}=\mathrm{Q}^{*}$ : optimal number of pieces to order

$\mathrm{D} \quad$ : annual demand in units for the inventory item

$\mathrm{C}_{\mathrm{o}} \quad$ : ordering cost of each order

$\mathrm{C}_{\mathrm{h}} \quad$ : holding or carrying cost per unit per year

$\mathrm{L} \quad$ : Lead time for a new order in days

d : demand per day

EOQ (Economic Order Quantity) is equal to $\mathrm{Q}^{*}$. Q* is used to count how many units we need for every order to get the minimum inventory cost but get the optimal number of units according to demand.

Total cost is how much cost we need per year. As explained above that total inventory costs (total cost) include holding costs and ordering costs, then the total cost is the sum of the holding costs per year and ordering costs per year.
The reorder point shows us, we must repeat the order when the remaining stock is equal reorder point. Reorder point help us to control stock to avoid running out of stock.

Frequency order is how many times we need to repeat orders per year. Frequency order also helps us to control ordering. It will greatly affect inventory costs. The more often we place orders, the greater the cost of ordering. If the ordering frequency is too small, the holding costs will be even greater.

The last step is the conclusion, where we will show and compare the actual data and the calculation results with the EOQ model. Then, compare the frequency ordering between actual data and the calculation of the EOQ model. Then, compare the total cost between actual data and calculation of the EOQ model.

Jona Shop especially Nutrisari products fulfilled all the assumptions in the EOQ model. From actual data, demand on Jona shop is always 90 units every day, lead time always only one day, the products always immediately use when received in one-time delivery. Jonas shop never repeat orders because of running out of stock. Jona shop never gives or get a discount on a specific purchase or sale amount. Because this shop was only established one year ago, so it is assumed that holding costs and ordering costs are constant. So, the author concludes that using the EOQ method is so accurate to help resolve the problem in Jona Shop.

\section{RESULTS AND DISCUSSION}

From Jona Shop in 2019, the author knows demand and considered it constant, then for the lead time always constant and known in 2019. The product to be estimated is Nutrisari. Every order is accepted in one-time delivery and can be used right away, there is no backorder because run out stock, no discount, and the holding cost per year and the ordering cost per year are constant. Ordering costs are only transportation cost and communication cost IDR 100.000,00 per order. Holding costs are warehouse electricity costs and depreciation costs per unit per year, where the holding cost is IDR 16.425.000,00 per year.

Table 1 actual data in 2019

\begin{tabular}{ll}
\hline Demand & $\mathbf{3 2 . 8 5 0}$ unit \\
\hline $\begin{array}{l}\text { Ordering } \\
\text { Costs }\end{array}$ & IDR $100.000,00$ per order \\
\hline $\begin{array}{l}\text { Holding } \\
\text { Costs }\end{array}$ & IDR 500,00 per unit per year \\
\hline
\end{tabular}

So, from the actual data Annual holding cost is 32.850 * IDR 500,00 = IDR 16.425.000,00. Annual ordering cost is IDR $100.000,00 * 12=$ IDR 1.200.000,00. Because the shop's owner does the order every month throughout 2019. So total cost IDR 17.625.000,00.

$$
E O Q=Q^{*}=\sqrt{\frac{2 D C_{0}}{C_{h}}}=\sqrt{2 * 32.850 * \frac{100.000}{500}}=3.624,914 \text { units }=3.625 \text { units }
$$

Frequency order $=\frac{D}{E O Q}=\frac{32850}{3625}=9,06=10$ times 
From the estimation and data we have, we can conclude that the optimal order for Jona Shop in 2019 for ordering Nutrisari products is 3.625 units. Only 10 times the order needed for the whole year. But in reality, Jona Shop always orders once a month 2700 units. So, it can be concluded that the less order frequency then the bigger number of units to be ordered.

Annual ordering cost $=\frac{D}{Q} C_{0}=\frac{32.850}{3.625} * 100.000=I D R 906.207,00$

Annual holding cost $=\frac{Q}{2} C_{h}=\frac{3.625}{2} * 500=I D R 906.250,00$

Total Cost $=\frac{D}{Q} C_{0}+\frac{Q}{2} C_{h}=I D R 906.207,00+I D R 906.250,00=I D R 1.812 .457,00$ $R O P($ reorder point $)=d * L=90 * 1=90$ units

From the estimation, we got that the expense for ordering costs in a year is IDR 906.207,00. Then for the holding costs or carrying cost is IDR $906.250,00$ per year. So, the total cost is IDR $1.812 .457,00$. The reorder point (ROP) 90 units.

Table 2 compare costs between the actual in 2019 and calculation of EOQ

\begin{tabular}{ccc}
\hline & Actual & EOQ \\
\hline $\begin{array}{c}\text { Annual Holding } \\
\text { Cost }\end{array}$ & IDR 16.425.000,00 & IDR 906.250,00
\end{tabular}

\begin{tabular}{ccc}
\hline $\begin{array}{c}\text { Annual Ordering } \\
\text { Cost }\end{array}$ & IDR 1.200.000,00 & IDR 906.207,00
\end{tabular}

\begin{tabular}{ccc}
\hline Frequency & 12 & 10 \\
\hline $\begin{array}{c}\text { Average number of } \\
\text { pieces to order per } \\
\text { order }\end{array}$ & $2.737,5$ units & $3.624,914$ units \\
\hline Total Cost & IDR 17.625.000,00 & IDR 1.812.457,00 \\
\hline
\end{tabular}

From table 2, we can compare the actual data and the calculation results of the EOQ model. The annual holding cost from actual data is IDR 16.425.000,00 and from the EOQ model, we get IDR 906.250,00. The annual ordering cost from actual data is IDR 1.200.000,00 and from the EOQ model, we find these costs to be less than the actual data, IDR 906.270,00. The order frequency in the EOQ model is also less than the actual data. From actual data is 12 times in order and the calculation of the EOQ model is 10 times. The average number of pieces to order per order from actual data is $2.737,5$ units, but from the EOQ model, we get the average number of pieces to order per order more than actual data, 3.624,914 units. So, we know that the actual data always costs more than the EOQ model calculation. Thus, the total cost of the actual data is also greater than the calculation of the EOQ model, where the actual data for total cost is IDR 17.625.000,00 and from the calculation of EOQ model is IDR 1.812.457,00.
Table 3 difference between Actual and EOQ

\begin{tabular}{ccc}
\hline & Difference & Difference (\%) \\
\hline $\begin{array}{c}\text { Annual } \\
\text { Holding Cost }\end{array}$ & IDR 15.518.750,00 & $94,48 \%$ \\
\hline $\begin{array}{c}\text { Annual } \\
\text { Ordering Cost }\end{array}$ & IDR 293.793,00 & $24,48 \%$ \\
\hline Frequency & 2 & $1,67 \%$ \\
\hline $\begin{array}{c}\text { Average } \\
\text { number of } \\
\text { pieces to order } \\
\text { per order }\end{array}$ & 887,414 units & $32,417 \%$ \\
\hline Total Cost & IDR 15.812.543,00 & \\
\hline
\end{tabular}

From the table above, we can say that with the EOQ model, the shop's owner can save much cost. For Annual holding cost shop owner can save more than 90\% (exactly $94,48 \%$ ) where the difference cost is IDR 15.518.750,00. Annual ordering cost, the shop's owner can save $24,48 \%$ where the difference cost is IDR 293.793,00. The difference in frequency ordering per year is 2 times $(1,67 \%)$. The difference in the average number of pieces to order per order is 887,414 units, it is $32,417 \%$. So, for the total cost, the shop's owner can save cost almost $90 \%$ (exactly $89,72 \%$ ).

\section{CONCLUSION}

Based on results, EOQ method can save total cost until 89,72\% (IDR 15.812.543,00), annual holding cost until $94,48 \%$ (IDR 15.518.750,00), and annual ordering cost until $24,48 \%$ (IDR 293.793,00) for Jona Shop especially Nutrisari products. From the EOQ model, the owner only requires an annual holding fee of IDR 906.250,00. Ordering costs per year that need to be issued is IDR 906.207,00. It is enough to place orders 10 times a year and each order 3.625 units. So that the total cost required is only IDR 1.812.457,00. So actual costs in 2019 are not effective especially on the holding cost. The order frequency quite effective even it's a bit different from the EOQ result. The approximation that the shop's owner thinks that the inventory cost is too big is true when we see the EOQ result.

The authors hope there is another author that creates a specific model if other possibilities happen out of Jona Shop control. It is very possible that this shop is using other modeling calculations because it has only been around for one year. So that there is a big opportunity for the next researcher what model is suitable in calculating inventory costs for this shop. The calculated modeling does not think about changes in ordering costs or holding costs at any time. Then the calculation also does not consider changes in demand at any time. It may be that in the following years' shop owners did some back-ordering. There are still many other possibilities for this shop so that it can still be developed to calculate inventory costs with other models. The next researcher also has the opportunity to calculate using modeling on beverage products other than Nutrisari which are sold by Jona shop. Even further researchers can also calculate inventory costs by creating a model to apply all products sold by Jona shop. 


\section{REFERENCES}

Burwell, T. H., Dave, D. S., Fitzpatrick, K. E., \& Roy, M. R. (1997). Economic lot size model for price-dependent demand under quantity and freight discounts. International Journal of Production Economics, 48(2), 141-155. Retrieved from https:// www.sciencedirect.com/science/article/abs/pii/ S0925527396000850

Datta, T. K., \& Pal, A. K. (1988). Order level inventory system with power demand patterns for items with variable rate of deterioration. Indian Journal of Pure and Applied Mathematics, 19(11), 10431053. Retrieved from https:/insa.nic.in/writereaddata/UpLoadedFiles/IJPAM/20005a79_1043. pdf

Dobson, G., Pinker, E. J., \& Yildiz, O. (2017). An EOQ model for perishable goods with age-dependent demand rate. European Journal of Operational Research, 257(1), 84-88. Retrieved from https:// www.sciencedirect.com/science/article/abs/pii/ S0377221716305367

Fadly, M., Jaya, A. I., \& A.Sahari. (2016). ANALISIS DAN OPTIMALISASI PERSEDIAAN BAHAN BAKAR PEMBANGKIT LISTRIK PADA PT. KUTILANG PAKSI MAS DENGAN METODE ECONOMIC ORDER QUAANTITY (EOQ). Jurnal Ilmiah Matematika dan Terapan, 13(2), 25-34. Retrieved from https://bestjournal.untad.ac.id/index.php/JIMT/article/download/7202/5793

Hoswari, S., Gozali, L., Marie, I. A., \& Sukania, I. W. (2019). Comparison Study about Inventory Control System from Some Papers in Indonesian Case Study. IOP Conference Series: Materials Science and Engineering. Jakarta, Indonesia. Retrieved from https://iopscience.iop.org/article/10 $.1088 / 1757-899 \mathrm{X} / 852 / 1 / 012110 /$ meta

Huang, B., \& Wu, A. (2016). EOQ model with batch demand and planned backorders. Applied Mathematical Modelling, 40(9-10), 5482-5496. Retrieved from https://www.sciencedirect.com/science/article/ pii/S0307904X16000068

Jiraruttrakul, R., Smutkupt, S., Marksin, W., Liu, L., \& Thanathawee, C. (2017). APPLYING AN EOQ MODEL TO REDUCE AN INVENTORY COST. Journal of Supply Chain Management, 11(1), 46-55. Retrieved from https://jscm.au.edu/ index.php/jscm/article/view/140/103

Kumar, D. R. (2016). Economic Order Quantity (EOQ) Model. Global Journal of Finance and Economic Management, 5(1), 1-5. Retrieved from http:// www.ripublication.com/gjfem16/gjfemv5n1_01. pdf

Mishra, U. (2016). An EOQ Model with Time Dependent Weibull Deterioration, Quadratic Demand and Partial Backlogging. International Journal of
Applied and Computational Mathematics, 2, 545-593. Retrieved from https://link.springer. com/article/10.1007/s40819-015-0077-z

RENDER, B., RALPH M. STAIR, J., \& HANNA, M. E. (2012). Quantitative Analysis for Management Eleventh Edition. Boston: Pearson Education Limited.

Riza, M., Purba, H. H., \& Mukhlisin. (2018). THE IMPLEMENTATION OF ECONOMIC ORDER QUANTITY FOR REDUCING INVENTORY COST. Research in Logistics \& Production, 8(3), 207-216. Retrieved from http://yadda.icm.edu. $\mathrm{pl} / \mathrm{baztech} / \mathrm{element} / \mathrm{b} w \mathrm{meta}$.element.baztechdd51cb6e-fe26-432f-861c-08bbb3b40ea2

Sari, L. K., Dur, S., \& Husein, I. (2020). Using of EOQ and EPQ Methods in Minimizing Inventory Cost of Crude Palm Oil. Zero: Jurnal Sains, Matematika, dan Terapan, 4(1), 36-43. Retrieved from http://jurnal.uinsu.ac.id/index.php/zero/article/ view/7935

Tavakoli, S., \& Taleizadeh, A. A. (2017). An EOQ model for decaying item with full advanced payment and conditional discount. Annals of Operations Research, 415-436. doi:https://doi.org/10.1007/ s10479-017-2510-7

Tipaka, Y., Paendong, M., \& Mongi, C. (2017). ANALISIS PENGENDALIAN PERSEDIAAN BAHAN BAKU BUNGA KRANS PADA USAHA BUNGA PLASTIK DENGAN MENGGUNAKAN METODE ECONOMIC ORDER QUANTITY DAN METODE ECONOMIC PRODUCTION QUANTITY. Jurnal Ilmiah Sains, 17(2), 89-99. Retrieved from https://ejournal.unsrat.ac.id/index.php/JIS/article/view/16651/0

Topowijono, C. Y., \& Sudjana, N. (2016). PENERAPAN MODEL EOQ (Economic Order Quantity) DALAM RANGKA MEMINIMUMKAN BIAYA PERSEDIAAN BAHAN BAKU (Studi Pada UD. Sumber Rejo Kandangan-Kediri). Jurnal Administrasi Bisnis (JAB), 36(1), 1-9. Retrieved from http://administrasibisnis.studentjournal. ub.ac.id/index.php/jab/article/view/1389

Umami, D. M., Mu'tamar, M. F., \& Rakhmawati, R. (2018). ANALISIS EFISIENSI BIAYA PERSEDIAAN MENGGUNAKAN METODE EOQ (ECONOMIC ORDER QUANTITY) PADA PT. XYZ. Jurnal Agroteknologi, 12(1), 64-70. Retrieved from https://jurnal.unej.ac.id/index.php/JAGT/ article/view/8100 